2009) places the origins of the Industrial Revolution in the British Midlands in the eighteenth and early nineteenth centuries. In Allen's view, the only route to modern economic growth required an array of elements never seen together before in Britain. Among them were high, imperialism-driven wages; cheap coal next to an ample canal network; and an open trading network allowing for a vast expansion of textile exports. .

There are other well-argued views. Michael Kremer holds that the roots of economic growth lie in the drift of the long run of history: growing populations intent on improving productive efficiency added to the accumulated knowledge behind technological innovation, adaptation and deployment. Avner Greif, Daron Acemoglu, Simon Johnson and James Robinson maintain that a virtuous circle of growth was set in motion by British institutions that emerged between 1500

"Perhaps
10,000 educated
Europeans
thought of
themselves as
participants
in the search
for useful
knowledge."
and 1800 , making economic cooperation and exchange more attractive than extracting wealth at the point of a spear (or a writ). It might have been luck. Or it might have been a combination of factors that do not correspond neatly to how subdiscipline-focused historians and social scientists have conceptualized the issues.

Is Mokyr's argument correct? For me, the balance of probabilities favours Allen's explanation above. Yet I do not think there will be consensus on this issue. And I would not be greatly surprised if I were wrong, and Mokyr's brief - for it is a brief, and not a balanced presentation of the live possible theories - turned out to be the most broadly correct analysis.

Mokyr concludes with a broadside. $\mathrm{He}$ accuses most of us concerned with the causal factors of the Industrial Revolution of taking too narrow a view of what it actually consisted of. To him, the mechanisms through which early European intellectuals affected technological progress are deeper and more complex than simply, 'How much science was needed to build a spinning jenny?'. Industrialization also heralded waves of science; they grew in tandem. Ultimately, without the impetus of science, economic growth would have fizzled out after 1815. A Culture of Growth is certainly making me rethink.

Brad DeLong is an economic historian at the University of California, Berkeley. e-mail:brad.delong@gmail.com

\section{Life at the deep end}

\section{Sonja-Verena Albers reviews a riveting chronicle tracing the discovery of archaea.}

I n Microbes from Hell, molecular biologist Patrick Forterre narrates the intriguing history of the discovery of archaea, single-celled microorganisms with no distinct nucleus that may have evolved as long ago 4 billion years. It was Forterre who, in the 1980s, found that certain archaea wind their DNA using reverse gyrase enzymes, which work differently from the gyrase found in bacteria. This is history told by a scientist who helped to make it.

Forterre was fascinated by the ideas of microbiologist Carl Woese. In the 1970s, Woese realized that 'archaebacteria' were distinct from bacteria, for instance in the sequences of their ribosomal RNA. In 1990, Woese and his colleagues proposed to divide life into three domains: bacteria, archaea and eukaryotes. The concept has gradually been accepted, but Forterre - with microbiologists Wolfram Zillig and Otto Kandler, among others - was an early 'believer'.

As he relates, most of the archaea that had then been isolated were extremophiles. These include hyperthermophilic microbes that thrive above $80^{\circ} \mathrm{C}$ and are typically found in habitats such as deep-ocean vents. Up to the 1970s, the consensus had been that most such habitats were hostile to life, but a handful of groundbreaking microbiologists changed that. Thomas Brock, for instance, began to isolate hyperthermophilic archaea, including the genus Sulfolobus, from hot springs in Yellowstone National Park, Wyoming. Later, German microbiologist Karl Stetter showed that many surprising habitats, even oil fields, teemed with microbial life.

In the 1980s, Forterre began to analyse the hyperthermophilic archaea isolated by Stetter and Zillig, looking for reverse gyrase. The enzyme causes the DNA double helix to cross over on itself (supercoiling), and Forterre discovered that hyperthermophiles contain a form of it that induces positive supercoiling - adding extra twists. This enzyme, also found in hyperthermophilic bacteria, has not yet been seen in organisms growing at lower temperatures, leading to speculation that it might be one reason that hyperthermo-
Microbes from Hell PATRICK FORTERRE (TRANSL. TERESA LAVENDER FAGAN) University of Chicago Press: 2016. philes can grow at such high temperatures. One theory is that the enzyme is important in sensing unpaired regions in hyperthermophile genomes, then initiating repair.

In 1999, Forterre and his technician (later wife) Évelyne Marguet joined the AMISTAD expedition of the French National Center for Scientific Research and the French Research Institute for Exploration of the Sea. Its aim was to isolate hyperthermophilic archaea from the deep eastern Pacific Ocean. Marguet gives a rousing account of her 2,600 metre dive in the submersible Nautile to gather samples from 'smokers'. These rock chimneys form at geologically active sites on the sea floor, where superheated, metalladen water is funnelled from vents.

Back on the ship Atalante, Marguet was enthralled to see cells growing in cultures from her samples, and isolated several Thermococcus species. She also tried to isolate the first viruses from these archaea, using methods established by Zillig. She and Forterre discovered no viruses, but they did find that Thermococcus strains produced a vast amount of membrane vesicles from cells containing plasmid DNA. Since then, large quantities of membrane vesicles have been found, particularly in ocean water, and produced by eukaryotes and bacteria. They are thought to contribute to DNA transfer between species, so they may have a role in evolution.

Ever since Forterre read Woese's work on the identification of the archaea and its implications for the tree of life, he has wondered about a last universal common ancestor of all life. His book walks the reader through his fascinating journey to understand how life evolved. Today, Forterre believes that viruses played a vital part. Microbes from Hell, in interweaving a scientific life with the grand discovery of the archaea, is a wonderful homage to this exciting field, which continues to challenge our view of life's origins.

Sonja-Verena Albers is professor of microbiology at the University of Freiburg in Germany.

e-mail:sonja.albers@biologie.uni-freiburg.de 